| GOSOS | Gaziosmanpaşa Üniversitesi Sosyal Bilimler Araştırmaları Dergisi/GOSOS Gaziosmanpasa University Social Sciences Researches Journal

(Yaz 2015) 10/1: 99-117/(Summer 2015) 10/1: 99-117

\title{
Güney Kafkasya Enerji Koridoru: Alternatif Projeler Kapsamında, “TANAP”
}

\begin{abstract}
Mehmet Dikkaya ${ }^{1}$, Abdülkadir Tığlı ${ }^{2}$
Avrasya'nın ü̧̈ sancilı bölgesi; Balkanlar, Kafkasya ve Orta Doğu düzleminde Güney Kafkasya, son zamanlarda enerji kaynakları açısından uluslararası kamuoyunun dikkatini çeken bir coğrafya haline gelmiştir. Bölge, enerji kaynakları ve iletimi konusunda Batı'nın enerji güvenliği kaygıların giderebilecek önemli bir potansiyele sahiptir. Alternatif projeler

$\ddot{O} z$ kapsamında somut olarak Trans Anadolu Doğalgaz Hattı Projesi (TANAP), uluslararası piyasalarda enerji tekelini zayıflatma potansiyeli taşımaktadır. Türkiyénin, bu coğrafya üzerindeki yaklaşım ve politikaları başta Rusya olmak üzere Batılı ülkelerce dikkatle izlenmektedir. Türkiye, Doğu ile Batı arasında enerji koridoru olma noktasinda Güney Kafkasya coğrafyasına önemli katkılar sağlayacaktır.
\end{abstract}

Anahtar Kelimeler: Enerji Güvenliği, Doğalgaz İletimi, Jeopolitika, Transkafkasya Ekonomi Politiği.

The Southern Caucasus Energy Transmission Line: A Case for Alternative Projects, "TANAP"

\begin{abstract}
Nowadays, Southern Caucasus gained importance throughout the world regarding its energy sources among three painful regions of Eurasia; Balkans, Caucasus and Middle East triangle. This region has important potential on energy sources and transport to Western countries which has anxieties about their energy security. Among alternative projects, the Trans Anatolian Natural Gas Pipeline Project (TANAP) will reduce monopoly power in international energy markets. Turkey's approach and policies towards this region has been followed by Western countries and especially by Russia. Turkey will provide serious contributions to Southern Caucasus along Eastern-Western energy corridor.
\end{abstract}

Keywords: Energy Security, Natural Gas Transmission, Geo-politics, Political Economy of Transcaucasia

\footnotetext{
1 Prof. Dr., Kırıkkale Üniversitesi, İktisadi ve İdari Bilimler Fakültesi, İktisat Bölümü, e-mail: mdikkaya@yahoo.com 2 Yüksek Lisans Öğrencisi, Kırıkkale Üniversitesi, Sosyal Bilimler Enstitüsü, İktisat Anabilim Dalı, e-mail: abdulkadirtigli@yahoo.com
} 


\section{GİRIŞ}

Milletler ve diller cenneti Kafkasya, jeopolitik ve jeostratejik konumuyla tarih boyunca büyük güçlerin ilgi odağı olmuştur. Enerji kaynaklarının varlığı anlaşıldıktan sonra daha da yoğunlaşan uluslararası ilgi, yerini etnik çatışmalar, iç savaşlar, heterojen iskân politikaları sorunlarına bırakmıştır.

Hazar'daki zengin petrol ve doğalgaz rezervleri, Azerbaycan, Ermenistan ve Gürcistan hattının enerji transferinde bir koridor olması, Orta Asya'nın enerji ve ihracat pazarını Batı yanlı transit yollar ile sağlamaya çalışması; 21.Yüzyılın başından bu yana bölgenin restleşme alanı haline gelmesine neden olmuştur. Rusya, izlediği ayrıştırıcı politikalarla nüfuzunu korumaya çalışırken; $A B D$, büyük ve çok uluslu şirketleri vasıtasıyla bu coğrafyada yürütmeye çalıştığ pay sahibi olma politikaları ile Transkafkasya olarak anılan Güney Kafkasya bölgesini sürekli dünya gündeminde tutmuştur. Nitekim pek çok Batılı stratejist ${ }^{3}$, bölge coğrafyası üzerinde hâkimiyet teorileri üretmiş, özellikle bu bölgeye hâkim olmanın bütün bir Avrasya, yerine göre Afro-Avrasya ${ }^{4}$ (Euroafrasia) bölgesine hâkim olma anlamı taşıdığını dile getirmiştir.

Brzezinski'nin (2005: 175), “Avrasya'nın Balkanları" 5 olarak tanımladığı ve Türkiye' nin de yakından ilgilendiği bu coğrafya, gerek tarihten gelen ortak değerlerin olması, gerekse bölgenin diğer pazarlara açılımı noktasında köprü vazifesi görmesi sebebiyle, Soğuk Savaş sonrası uluslararası paradigmaları değiştiren önemli ve stratejik bir bölgedir.

Sadece enerji havzası değil, aynı zamanda enerji nakil güvenliği yönüyle de, yeniden canlandırılmaya çalışılan tarihi İpek Yolu kapsamında, 2008 Küresel Krizi sonrası Asya'da yükselen ekonomiler (Çin ve Hindistan gibi) enerji tüketiminin Avrupa'ya mı yoksa Güneydoğu Asya'ya mı kayacağı konusunda küresel bir rekabete

\footnotetext{
${ }^{3}$ Halford J. Mackinder, Nicholas J. Spykman, Milan Hauner, Karl E. Haushofer, Friedrich Ratzel, Samuel P. Huntington, Zbigniew K. Brzezinski gibi.

${ }^{4}$ Afrika ve Avrasya'nın bütünü.

${ }^{5}$ Avrupa'da Balkan coğrafyası; siyasi krizler, etnik ve dinsel ayrımcılık propagandaları sonucu tarih boyunca uluslararası kamuoyunun hafızasında hep sorunlu bölge olarak kalmıştır. Kafkasya coğrafyası da Avrasya'da paralel görünüm sergilediği için, yazar tarafından bu bölgeye “Avrasya'nın Balkanları" yakıştırması yapılmıştır.
} 


\section{| MEHMET DİKKAYA ve ABDÜLKADİR TIĞLI}

(Yıldıran, 2013: 108) yol açarak, İpek Yolu ekonomilerini, ${ }^{6}$ Hazar enerji potansiyeli üzerinde plan ve projeler yapmaya itmiştir. Deniz ulaşımına kapalı olması sebebiyle kara ulaşımına mahkûm olan İpek Yolu ticaret bölgesinin, Batı dünyasına yapacağ 1 enerji nakilleri noktasında güvenli olmayan Rusya-Ukrayna hattına alternatif olarak Transkafkasya ve Türkiye'yi tercih etmeleri kaçınılmaz olmaktadır. Bu alternatif model, Güney Kafkasya bölgesini doğu-batı hattında stratejik bir konuma getirmektedir.

Çalışmada, ilk olarak Güney Kafkasya coğrafyasının fiziki, etnik ve demografik yapısına genel hatlarıyla kısaca değinilecek; tarihî süreçte bölge üzerinde meydana gelen çeşitli sosyo-ekonomik sorunsallar nazara verilerek, bölgenin ekonomi politiği analiz edilmeye çalışılacaktır. Daha sonra Transkafkasya üzerinde somut olarak durulacak ve bölgesel rolü ortaya konulacaktır. Akabinde, Türkiye'nin de dâhil olduğu bölge coğrafyasında enerji iletimi konusunda gerçekleştirilen alternatif projelere, başlıklar cihetinde kısaca değinilecek ve alternatif projeler kapsamında Trans Anadolu Doğalgaz Hattı Projesi'nin (TANAP) ortaya çıkışı, tarafları, projenin yürütülmesine dair teknik bilgiler ve mahiyetine ilişkin değerlendirmeler yapılacaktır.

\section{GÜNEY KAFKASYA: GENEL BÖLGESEL PROFIL}

Kafkasya bölgesinin güneyinde bulunan coğrafya, uluslararası ilişkiler literatüründe Güney Kafkasya (Southern Caucasus) ya da Transkafkasya (Transcaucasus) olarak geçmektedir. Kuzeyde, Karadeniz'in kuzeydoğusundan başlayarak, Azak Denizi ile Hazar Denizi'ne kıyısı bulunan başkent Bakü'ye kadar olan hat boyunca, güneyinde İran, doğusunda Hazar Denizi ve batısında Türkiye bulunan coğrafyada, ülke olarak Azerbaycan, Ermenistan ve Gürcistan'dan müteşekkildir.

Bölgede dikkat çeken lokasyon, Hazar Denizi'dir. Hazar'ın göl olduğunu savunan İran ve Rusya'nın geçmişte kendi aralarında yaptıkları anlaşmalara dayandırdıkları savı gereği (Oruç, 2014: 92; İşcan, 2010: 68, 69, 70, 71), çevre ülkelerin Hazar'ın her noktasında müteselsil hak sahibi olduğunu öne sürmektedir. Deniz statüsü ile bölünmüş alanlara göre hak sahibi olmayı savunan Azerbaycan ve Kazakistan, Hazar kıta sahanlığında zengin petrol ve doğalgaz kaynaklarına sahip olduğu için ve yine ayrıca Birleşmiş Milletler Deniz Hukuku Sözleşmesi'nin ilgili

\footnotetext{
6 Rusya, Kazakistan, Çin, Hindistan, Güney Kore, Moğolistan, Azerbaycan, Ermenistan, Türkiye, Tacikistan, Özbekistan, Türkmenistan, Kırgızistan, Ukrayna, Irak, İran, Afganistan ve Pakistan İpek Yolu ülkeleri olarak bilinmektedir.
} 
hükümlerini7 ${ }^{7}$ (Kısım: IX, 122 ve 123. maddeler) dayanak göstermek suretiyle Hazar'1 deniz statüsünde değerlendirmektedir. Bu konuda son dönemde ortak bir görüşe doğru, bölge ülkeleri arasında uzlaşmanın ortaya çıkma eğiliminin güçlendiği görülmektedir. Yeni uzlaşma, Rusya'nın hazar kıyılarında da enerji kaynaklarının tespiti ile deniz statüsüne doğru evrilmiş görünmektedir.

Çok kültürlü ve çok lisanlı mozaik bir yapı olarak karşımıza çıkan Güney Kafkasya, fizikî açıan bir bütünlük göstermesine (Taşdemir ve Hasanoğlu, 2003: 95) rağmen; 1991'de Sovyetler Birliği'nin hukuken dağılması ile birlikte, Rusya'nın bölgede söz sahibi olmak istemesinden kaynaklanan böl-yönet politikalarının devam etmesiyle istikrardan uzak bir siyasi profile sahiptir.

Bölgedeki ülkelere ve özerk yapılanmalara, oluşum süreçlerine, ekonomi politik potansiyellerine göre Güney Kafkasya ülkeleri için şu tanımlama son derece isabetlidir: “Gürcistan, coğrafi konumu ile Azerbaycan, ekonomik potansiyeli, doğal zenginlikleri ve nüfusunun büyüklüğ̈̈, Ermenistan, Rusya ile kurduğu askeri işbirliği ve bölgede oynadığ 'çözülme' rolü temelinde stratejik önem arz etmektedirler" (Şen, 2009: 9).

\section{EKONOMİ-POLITIKK AÇISINDAN GÜNEY KAFKASYA}

Bölgenin ekonomi politiği, sancılı bir geçişin ardından Azerbaycan'ın 1990'ların ortalarından itibaren istikrara kavuşması ve enerji kaynaklarını uluslararası alana açması, iki binlerin başından itibaren de Türkiye üzerinde kaynaklarını Batı'ya transfer etmeye başlaması ile şekillenmektedir. Bu bağlamda Gürcistan, hem Batı hem Türkiye için Hazar kaynaklarının transferinde pozitif bir katkı oynamaya başlamış,19.Yüzyılın başlarından itibaren Rusların milliyetçilik pompalayan emperyal politikaları (Yılmaz, 2013: 73, 74) ile Karabağ problemini ulusal dış politika olarak ilan eden Ermenistan ise, sistem dışı kalmaya devam etmiştir.

2.1. Azerbaycan: Sancılı Bağımsızlık Sonrası Ekonomi-Politik Yıldızın Yeniden Parlaması

Son imparatorluk Sovyetler Birliği'nde, sosyalist sistemin fiyat denetleme mekanizması üzerinde etkinsizleşmeye başlaması ve daha birçok yapısal sorunların, Gorbaçov'un çabalarına rağmen (Dikkaya, 2009: 50) 1980'lerin sonlarına yaklaştıkça; merkezî planlamayla yürütülen üretimde yaşanan arz azalışı ve talep enflasyonunun

7 Birleşmiş Milletler, http://www.un.org/depts/los/convention_agreements/texts/unclos/unclos_e.pdf.s.67 


\section{| MEHMET DİKKAYA ve ABDÜLKADİR TIĞLI}

baş göstermesi, konjonktürel değişime ayak uyduramamanın bedelini ödemesi ve rublenin dolar karşısında aynı hızla erimesi (Cafersoy, 2011: 14), Azerbaycan'ın bağımsızlık sürecini de, diğer cumhuriyetler gibi hızlandırmıştır.

Azerbaycan'ın, halen devam eden sınır sorunlarından biri Dağlık Karabağ'dır. Bölge, idari birim statüsü olmayan (Aslanl1, 2011: 163) Azerbaycan ve Ermenistan sınırında, Azerbaycan'a bağlı özerk bir bölgedir. Ermeni kökenli nüfusun zamanla artırıldığı Dağlık Karabă̆, Ermenistan'ın tam bağımsızlık talep ettiği ve fakat Azerbaycan'ın en yüksek düzeyde özerklik kabul edebildiği bölge olarak durmaktadır (Yilmaz, 2012: 58).

Nahcivan Özerk Cumhuriyeti ise, Azerbaycan ile karasal bir bağı bulunmadiğ1 halde, bu ülkeye bağlı özerk bir cumhuriyet olarak kurulmuş, Ermenistan'ın güneybatısı ile Türkiye ve İran arasında küçük bir coğrafyadır ${ }^{8}$ Nahcivan'da göze çarpan en bariz sosyo-politik sorun, Rusya'nın alışılagelmiş iskân politikaları çerçevesinde, İran'da yaşayan bazı Ermenilerin Nahcivan'ın şimdiki coğrafyasına yerleştirilmesi olmuştur.

Ülkenin uluslararası ekonomi politiği üzerinde, iki argümanın varlığını kabul etmek isabetli olacaktır. Bunlardan birincisi, Hazar havzası zengin enerji kaynaklarının büyük bir kısmının Azerbaycan'ın Hazar kıyılarında bulunmasıdır. Ülkenin petrol üretiminin ve ihracatının 3/4'ünün Hazar Havzasından temin ediliyor olması (Metin, 2004: 80), dünya doğalgaz rezervinin yaklaşık \% 0,7'sinin Hazar kaynaklı olması, Azerbaycan'ın jeopolitik önemini artırmaktadır. İkinci argüman, Güney Kafkasya hattında Rusya'nın enerji güvenliğine yönelik takındığı tehditkâr tutumla birlikte coğrafi şartlar dikkate alındığında, kuzey-güney geçişinin risk oluşturması nedeniyle, doğu-batı geçişinin alternatif fırsat oluşturmasıdır. Azerbaycan'ın, sadece sahip olduğu hidrokarbon enerji rezervi bağlamında değil, aynı zamanda; “Orta Asya $\rightarrow$ Hazar $\rightarrow$ Güney Kafkasya $\rightarrow$ Türkiye $\rightarrow$ Batı" koridorunda önemli geçiş güzergâhı olması ile değerlendirilmesi gerekirse, Orta Asya' da Kazakistan'dan sonra ikinci büyük ekonomi olarak makro avantajı sağlayacağı öngörülebilir.

$\mathrm{Bu}$ iki argüman etrafında, hem kaynak hem de enerji koridoru kazanımının Rusya'nın tekeline terk edilemeyecek kadar önemli çapta olduğunu gözlemleyen ABD

(Erişim Tarihi: 19.11.2013)

${ }^{8}$ Azerbaycan Anayasasi, 134.vMadde, http://www.anayasa.gen.tr/azerbaycan-aleskerli.htm (Erişim Tarihi: 22.01.2015) 
ve Batı kökenli çok uluslu şirketler, 1990'lı yılların ortalarından itibaren enerji üretim, işletme ve iletim hatlarında pay sahibi olmaya başlamışlardır. Buna rağmen ülke, liberal politikalarla gerçekleştirmeye çalışsa da; hâlâ İran ve Rusya'nın baskılarına maruz kalmaktadır.

\subsection{Gürcistan: Ayrılıkçı Sorunların Gölgesinde Yeni Fırsat Alanları}

Soğuk Savaş sonrası tek kutuplu dünya düzenine geçiş ve Kafkasya'da 1990'l1 yıllarda başlayan etnik çatışmalar Gürcistan'ı derinden etkilemiştir. 2008 yılında zirve yapan ve 15 yıldır devam eden Rusya-Gürcistan gerginliği ve Çeçen savaşları, Rus dış politikası tarafından ileride tekrar öne sürülmek üzere, bölgede etnik temelli özerk yapıların oluşmasına imkân vermiştir (Oğan, 2011: 193). Siyasi istikrarsızlığın durulmadı̆̆ı ülkede, dönemin cumhurbaşkanı Gamsakhurdia tarafından sürdürülen milliyetçi politikalar ve BDT üyeliğine karşı tutum, sonraki cumhurbaşkanı Şevardnadze'nin Rusya karşısındaki çaresizlikle BDT üyeliğini kabullenmek zorunda kalmasıyla sonuçlanmıştır (Şen, 2009: 27).

Rusya'nın ayrıştırıcı politikaları ile ülke sınırları içinde sorun alanları olarak oluş(turul)muş özerk bölgeler; "Abhazya", "Cevaheti", "Acaristan" ve "Güney Osetya" olarak sıralanabilir. Yirminci Yüzyılın başından, Soğuk Savaş'ın bitimine kadar büyük rekabete yol açan, tarihi İpek Yolu projesinin enerji ve ticaret yolu üzerinde önemli bir konuma sahip olan Gürcistan; Karadeniz kıyılarındaki limanları, Hazar-Karadeniz, Hazar-Türkiye hatlarındaki kara ulaşımı bağlamında uluslararası ticaret zincirinin önemli bir unsuru olmaktadır. Bu avantajlarına rağmen, Güney Kafkasya'da, jeokondüksiyonel pozisyonu ile bölgenin diğer ülkelerinden üstün, fakat barındırdığı çeşitli etnik unsurlarla dezavanataja sahip olan Gürcistan, “... ülke bütünlü̈̆̈̈̈ne yönelik siyasi ve ekonomik tedbirler almadiğı takdirde gelecekte iyice küçülerek, sadece Tiflis'e sıkışmı̧ bir Gürcistan haline gelebilir" (Kantarc1, 2011: 234).

\subsection{Ermenistan: Güney Kafkasya'da İzole Edilmiş Bir Rus Müttefiki}

Ermenistan, bir taraftan özellikle askerî alanda Rus-Ermeni ittifakı, diğer tarafta Türkiye-Azeri ittifakından ${ }^{9}$ kaynaklanan iki kutuplu bir siyasi sıkışmışlıkla göze

\footnotetext{
9 Aslında yakın geçmişe kadar Türkiye-Azerbaycan arasında olması beklenen müttefiklik ilişkisi, Yılmaz'ın (2009) da tespitiyle, çoğunlukla duygusallıktan öteye gidememiştir. Örneğin Başbakanlık Kamu Diplomasisi Koordinatörlüğ̈̈'nce yayımlanan "Türk Vatandaşlarının Vizesiz Gidebileceği Ülkeler" listesinde bugün itibarı ile Azerbaycan hâlâ bulunmamaktadır. http://kdk.gov.tr/sayilarla/turk-vatandaslari-70-ulkeye-vizesiz-seyahat-ediyor/10
} 


\section{| MEHMET DİKKAYA ve ABDÜLKADİR TIĞLI}

çarpmaktadır. Bağımsızlık sonrası, Sovyet döneminin işgalci ve hasmane politikalarını, kendi coğrafyasında sürdürme niyeti sergileyen Ermenistan'ın Dağlık Karabağ'1 işgalinden beri Azerbaycan ve Türkiye ambargosuna maruz kalması, zaten kaynakları ve üretim düzeyi düşük olan ülkeyi kapalı bir ekonomi haline getirmiştir.

Ermenistan, gerek Gürcistan'a karşı Rusya ile olan ittifakı, gerekse bu ittifak karşısında yükselen Gürcü milliyetçiliği açılarından bölgede milliyetçiliği körükleyen bir ülke olarak gündemde kalmıştır (Kasım, 2011: 58). Azerbaycan ve Türkiye'ye karşı takındığı hasmane tutumun altında da yine Ermeni milliyetçiliği yükselirken, diğer yandan diaspora Ermenileri küresel bir misyon üstlenerek, güdülen amacı politize etmektedirler.

Kaynak yoksunu ve jeopolitik konumu olmayan Ermenistan'ın Azerbaycan ve Türkiye tarafından ambargoya maruz kalması, ekonomik bağlamda ülkeyi Rusya eksenine yönlendirmektedir. "Müttefiki Rusya ile doğrudan karasal bağlantısı olmaması ise Ermenistan'ın kaderini Rusya-Gürcistan ilişkilerinin durumuna bağımlı kılmaktadır" (Veliev, 2011: 116).

\section{GÜNEY KAFKASYA-TÜRKIYYE EKONOMI POLITIİĞİ}

Türkiye'nin, Doğu-Batı koridoru olmanın verdiği güçle, sınırındaki Güney Kafkasya'ya duyarsız kalması düşünülemez. Türkiye' nin bölgeye ilgisi; tarihten gelen kültürel, dini ve etnik bağlar, Türkiye'ye sağlayacağı büyük ekonomik katkılar ve uluslararası sistem açısından bölgenin cazibe merkezi olması açılarından önemlidir.

Tarihi ve kültürel bağların yanı sıra; 1990'lı yıllara kadar TL'nin sürekli değer kaybına uğraması, Türkiye'yi ihracata dayalı bir ekonomik yapılanmaya doğru itmiş ve 1990'l1 y1llarda bu politika, özellikle Orta Asya ve Kafkasya üzerinde uygulanmak istenmiştir (Denizhan, 2010: 20). Çelikpala'ya göre (2010: 97) Türkiye, bugüne kadar Güney Kafkasya'da, ihracata dayalı potansiyelinin de verdiği teşvikle, aktif olmayan fakat etnik ve siyasi çatışmalar arasında arabuluculuk, müzakere davetçisi rolü ile boy göstermiştir.

Davutoğlu'nun işaret ettiği üzere (2010: 113), Ortadoğu'da petrol kaynakları, Türkiye'de Doğu Anadolu su kaynakları ve Transkafkasya-Hazar koridorunda petrol ve doğalgaz kaynakları arasında son derece önemli bir jeoekonomik hat olarak bulunmakla, üç kıta arasında bir "enerji havzası" pozisyonuna gelmektedir. Asya'nın,

(Erişim Tarihi: 20.04.2015) 
dünya doğalgaz üretiminin \% 25'ine sahip olması ve 2010 yılından 2030 yılına kadar bu üretimin \%45 oranında artırılmasının öngörülmesi (World Energy Council, 2013: 3.12), Türkiye'nin bir koridor işlevi açısından önemini artırmaktadır. Bu bağlamda Türkiye'nin, Transkafkasya'da etkin bir politika izlemesi soyut manada politika güvenliği, somut olarak da ekonomi politik güvenlik açısından önemlidir.

Burada, politika güvenliğinden kastedilebilecek bir İran ${ }^{10}$ boyutu; ekonomi politik güvenlik açısından işaret edilebilecek bir Rusya ${ }^{11}$ boyutundan söz etmek mümkündür.

\section{GÜNEY KAFKASYA'DA ALTERNATIFF PROJELER}

Soğuk Savaş sonrası, Orta Asya'nın sahip olduğu petrol ve doğalgaz, Rusya'nın duruma müdahale ederek Batı'ya karşı bir silah olarak kullanması hedefine dönüşmüştür. Petrol ve doğalgaz piyasasında kontrolü elinde tutmak isteyen Rusya ve İran'ın tekelleşmesini istemeyen NATO, ABD ve AB, muhtemel enerji krizini aşmak için alternatif koridor arayışına girmişlerdir. İşte bu noktada, ekonomi politik literatürüne "enerji güvenliği" terimi girmiştir. İçinde bulunduğu coğrafi konumunun Türkiye'ye, Hazar enerji kaynaklarını Avrupa'ya ulaştırmada fırsat oluşturduğu söylenebilir.

Enerji arz güvenliği açısından, bölgesel anlamda özellikle Rusya ile ilgili olarak enerji talep güvenliğinden de bahsedilmelidir. Öğütçü'nün (2010: 121) ifade ettiği gibi, AB'ye bağımlılığını azaltmak üzere Rusya'nın doğalgaz ihracatını, Asya pazarlarında geliştirmeyi amaçlaması, ihracatçı ülkeler açısından da enerji talep güvenliğini sağlama yönünde tedbirler almaya itmektedir. Enerji güvenliği kavramını, enerji arzı ve enerji talebi güvenliği şeklinde bir ayrıma tabi tutanlar da olmuştur (Gökdemir, 2009: 96).

İki binli yıllardan sonra enerji güvenliği kavramı, artık reel üretim sektörünü de ilgilendirmekte; üretim hacmi, piyasa esnekliklerine uyarlanabilme, fiyat mekanizması, arz ve talep dengesi gibi mikro karar birimlerinin gündemine girmektedir.

\subsection{Asrın Anlaşması}

Azerbaycan, bağımsılığını müteakiben sahip olduğu enerji kaynaklarını işletecek ve uluslararası piyasalara sunacak imkânlara sahip değilken, çok uluslu şirketlere açılan ihaleler vasıtasıyla bu pazardan payını alması gerekiyordu. İlk

10 İran'ın Batı dünyası ile olan politik ilişkileri.

${ }^{11}$ Rusya'nın Batı dünyası ile olan ekonomik ve hegemonik ilişkileri. 


\section{| MEHMET DİKKAYA ve ABDÜLKADİR TIĞLI}

cumhurbaşkanı Ayaz Muttalibov'dan sonra görevi devralan Ebulfez Elçibey zamanında ihaleye açılan Azeri, Çırak ve Güneşli sahaları için pek çok Batılı şirket ${ }^{12}$, 1993 yılındaki askeri darbenin ardından yeni cumhurbaşkanı Haydar Aliyev ile masaya oturmak durumunda kalmışlardır.

Aliyev zamanında Rusya'nın ortaklığa sonradan dahil olması (Aras, 2003: 121) sağlanmıştır. Bu entegrasyonla \% 10'luk payın Rusya'ya verilmesi sonucu, SOCAR'ın $\% 30$ olan payı, \% 20'ye gerilemiştir.

\subsection{Bakü-Tiflis-Ceyhan Petrol Boru Hattı (BTC)}

1992' de başlayan, 1999' da Türkmenistan, Azerbaycan, Gürcistan, Kazakistan ve Türkiye'nin hazır bulunduğu toplantıda bir konsensus sağlanarak 1076 km'si Türkiye'den geçen 1776 km'lik boru hattı projesine ilişkin çalışmalara fiilen başlanmıştır ${ }^{13}$. Dünya çapında günlük sevkiyatı yapılan petrolün \% 2,5'ini karşılayan BTC hattı ile Azerbaycan'ın Azeri, Çırak ve Güneşli alanlarından çıkarılan ham petrol, 2006 yılından bu yana Gürcistan ve Türkiye'de Ceyhan üzerinden dünya pazarına açılmaktadır (Pamir, 2011: 357).

Hekimoğlu'ya göre (2012: 78): “... ABD, $A B$ ve Türkiye'nin, projeye verdikleri büyük desteğin ardında kendi enerji güvenliklerine yönelik endişeleri bu tür projelerle giderme kaygısı yatmaktadır." Dünya enerji kullanımının hala en üst sırasındaki petrolü en çok tüketen ülkenin $\mathrm{ABD}^{14}$ olduğu kesindir.

\subsection{Bakü-Tiflis-Erzurum Doğalgaz Hattı (BTE)}

Doğu-Batı enerji koridorunun ikinci bileşeni olan Bakü-Tiflis-Erzurum (BTE) Doğal Gaz Boru Hattı, 3 Temmuz 2007'de faaliyete geçmiştir. Türkiye, Hazar'ın Azerbaycan kısmındaki Şahdeniz sahasının geliştirilen bölümünden çıkan doğalgazı tedarik etmektedir.15 2000 yılında başlayan ve 2001'de sonuçlanan, Azerbaycan

12 British Petroleum (İngiltere) \% 17.127, Amoco (ABD) \% 17.01, Lukoil (Rusya) \% 10, Pennzoil (ABD) \% 9.82, Unocal (ABD) \% 9.52, Statoil (Norveç) \% 8.563, McDermott International (ABD) \% 2.45, Ramco (İskoçya) \% 2.08, Türkiye Petrolleri Anonim Ortaklığ1 (Türkiye) \% 1.75, DeltaNimir (Suudi Arabistan) \% 1.69 (Sagheb ve Cavadi, 1994: 27).

${ }^{13}$ Bakü-Tiflis-Ceyhan Boru Hattı Projesi, http:/ / www.btc.com.tr/rakamlarlaproje.html (Erişim Tarihi: 12.01.2015)

${ }_{14}$ TC Enerji Bakanlığ 1 , http://www.enerji.gov.tr/yayinlar_raporlar/Dunyada_ve_Turkiyede_Enerji_Gorunumu.pdf (Erişim Tarihi: 03.01.2014) ${ }_{15}$ TC Dışişleri Bakanlığı, http://www.mfa.gov.tr/turkiye_nin-enerji-stratejisi.tr.mfa, (Erişim Tarihi: 20.12.2013) 
doğalgazının Türkiye'ye naklini öngören SOCAR ve BOTAŞ arasında imzalanan sözleşmeye göre projeyi, Gürcistan'a kadar SOCAR, Türkiye' de kalan 225 km'lik hattı ise BOTAŞ koordine etmektedir.

\subsection{Trans Adriyatik Boru Hattı (TAP)}

Azerbaycan, Şah Deniz-II alanından ilk etapta yıllık 16 milyar m³'lük

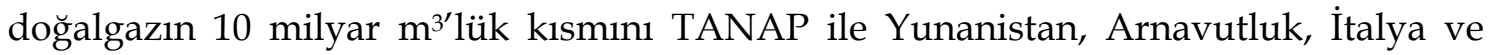
ileriki safhalarda diğer batı Avrupa ülkelerine taşıyacak olan TAP, rafa kaldırılan Nabucco'nun Avrupa ayağında gerçekleştirilmekte olan ve AB'nin kaygılarını giderecek olan ${ }^{16}$ önemli bir uzantıdır. TAP hattıyla TANAP'ın ilk gaz akımı aşamasında yıllık 10 milyar $\mathrm{m}^{3}$ iletilmesi öngörülürken, daha sonra kademeli olarak 20 milyar $\mathrm{m}^{3^{\prime}} \mathrm{e}$ kadar çıarılmak suretiyle, diğer güneydoğu ve uzun vadede ise batı Avrupa'nın doğalgaz tedarikçisi olma noktasına gelecektir.

\section{TRANS ANADOLU DOĞALGAZ HATTI PROJESİ (TANAP)}

Azerbaycan, Şah Deniz sahasında 1999 yılında tespit edilen doğal gaz rezervinin işletilmeye başlamasının ardından, net bir doğalgaz ihracatçısı haline gelmiştir. Uluslararası Enerji Ajansı (IEA) istatistiklerine göre Ocak 2013 itibarı ile Azerbaycan'da tespit edilen doğal gaz rezervi 35 trilyon $\mathrm{m}^{3}$ tür. 2012 yılı sonu verilerine göre Avrasya doğalgaz rezervinin \% 2'sine, Dünya doğalgaz rezervinin \% 0,5'ine ${ }^{17}$ sahip olan Azerbaycan'da enerji kaynakları \% 66 oranında doğalgaz, \% 31 oranında petrol, \% 3 oranında ise diğer hidrokarbon kaynakları olarak dağılmıştır. ${ }^{18}$

Gerek şu anda aktif durumda olan BTE, gerekse bir zamanlar şaşaalı bir proje olarak çokça gündeme gelen Nabucco ve gerekse TANAP projesi ile birleştirilme durumu ile karşı karşıya kalan TAP doğalgaz boru hattı projelerinde ana tedarikçi olarak Azerbaycan'ın Şah Deniz doğal gaz yatakları gösterilmektedir.

\subsection{Genel Olarak TANAP}

TANAP, Türkiye ile Azerbaycan arasında sadece iktisadi entegrasyon değil, diğer bağların da güçlenmesine katkı yapacak ve her iki ülke için uzun vadeli

${ }^{16} \mathrm{http}$ ://www.trans-adriatic-pipeline.com/tap-project/concept/

(Erişim Tarihi: 29.12.2013)

${ }^{17}$ http://www.bp.com/content/dam/bp/pdf/statisticalreview/statistical_review_of_world_e nergy_2013.pdf (Erişim Tarihi: 28.12.2013)

18 ABD Enerji Enformasyon Başkanlığı, http://www.eia.gov/countries/cab.cfm?fips=AI (Erişim Tarihi: 28.12.2013) 


\section{| MEHMET DİKKAYA ve ABDÜLKADİR TIĞLI}

getirisinin olması öngörülen büyük bir projedir. Söz konusu proje ile Türkiye'nin doğalgaz tedarikinde Rusya ve İran tekelinden kurtulması, aynı zamanda Azerbaycan'ın doğalgazının Batı'ya iletimi sağlanacaktır.

Azerbaycan ve Türkiye arasında iki ülke cumhurbaşkanları İlham Aliyev ve Abdullah Gül'ün katılımıla 7 Haziran 2010 tarihinde imzalanan gaz satış ve taşıma sözleşmesinin, aynı zamanda Azerbaycan Şah Deniz II sahasından çıkarılacak gazın Avrupa pazarlarına iletimi için de bir "prensip anlaşması" olduğu bildirilmiştir (Abbasov, 2010).

24 Aralık 2011'de ise projeye ilişkin iki ülke arasında Mutabakat Zapt1 imzalanmıştır. Bu zapta göre, proje faaliyetlerinin Azerbaycan Devlet Petrol Şirketi (SOCAR) tarafından yürütülmesi kararlaştırılmıştır. Daha sonra 17 Ocak 2013 tarihli Resmi Gazete' de yayımlanan 6375 Sayılı Onay Kanunu ile kabul edilmiş olan anlaşma, 26 Haziran 2012' de Türkiye ile Azerbaycan arasında imzalanmıştır. ${ }^{19}$

Türkiye'nin Gürcistan sınırından başlayarak Bulgaristan sınırında son bulması öngörülen hattın; Ardahan, Kars, Erzurum, Erzincan, Bayburt, Gümüşhane, Giresun, Sivas, Yozgat, Kırşehir, Kırıkkale, Ankara, Eskişehir, Bilecik, Kütahya, Bursa, Balıkesir, Çanakkale, Tekirdağ, Kırklareli ve Edine il sınırlarından geçmesi planlanmıştır20.

\subsection{Projenin Teknik Özellikleri ve Önemi}

Kurulacak boru hattının Türkiye sınırları içerisindeki uzunluğunun yaklaşık 1900 km olarak tasarlandığ 1 TANAP ekseninde, ilk etapta yıllık 16 milyar m³́lük geçiş öngörülen doğalgazın 6 milyar $\mathrm{m}^{3}$ ü Türkiye'de kalacaktır. Taşıma kapasitesi aşamalı olarak 2023 yılına kadar 23 milyar m³'e, 2026 yılına kadar da 31 milyar m³'e çıkarılması hedeflenmektedir. ${ }^{21}$

Bölgede gaz çeşitliliğinin sağlanmasını hedefleyen proje öncesinde büyük yatırımlara imza atan iki ülke arasında, BTC Boru Hattı ve BTE Doğalgaz Hattı Projeleri ile ivme kazanan stratejik işbirliği, 2008 yılında Azerbaycan Devlet Petrol

${ }^{19}$ T. C. Dışşsleri Bakanlığı, http:// www.mfa.gov.tr/turkiye_nin-enerji-stratejisi.tr.mfa (Erişim Tarihi: 20.12.2013)

${ }^{20}$ Trans Anadolu Doğalgaz Hattı Projesi (TANAP), http://www.tanap.com/wp-content/uploads/2013/03/liflet.pdf (Erişim Tarihi: 09.12.2013)

${ }^{21}$ Trans Anadolu Doğalgaz Hattı Projesi (TANAP) http://www.tanap.com/wp-content/uploads/2013/03/liflet.pdf (Erişim Tarihi: 09.12.2013) 
Şirketi SOCAR'ın PETKİM'i satın almasıyla daha kapsamlı hale gelmiştir (Baloğlu, 2010: 4). Projeyle İran ve Rusya'nın da ilgileniyor olması dikkatlerden kaçmamaktadır (Rzayeva, 2012). Batı'nın talepleri doğrultusunda oluşmuş olan enerji politikaları üzerine inşa edilmekte olan projeye, İran ve Rusya'nın ortak olma talepleri, pazara ortak olmak istemelerinden mi yoksa başka siyasi kaygılardan mı kaynaklandığı merak konusudur.

2013 Aralık ayında, Türkiye' nin BOTAŞ-TPAO konsorsiyumunun TANAP'taki payı \% 20'den 30'a çıkarılmış, böylece TANAP üzerindeki dağılım BP \% 12, SOCAR \% 58 ve Türkiye $\% 30$ olmuştur. ${ }^{22}$

Doğalgazda büyük oranda ithalata dayalı olan Türkiye'nin İran'dan ithal ettiği doğalgazın fiyatı, bin $\mathrm{m}^{3}$ bazında olmak üzere, 2012 yılının başlarında 585 dolar, Rusya'dan ithal ettiği doğal gazın fiyatı ise 400 dolar iken, yine 2012 yılı planlamalarına göre TANAP'tan tedarik edilecek doğalgazın fiyatı 330 dolar olması öngörülmektedir (Rzayeva vd., 2012: 5). İthal edilen doğalgazın fiyatı 2012 sonu itibarı ile İran'dan 530 dolar, Rusya'dan 445 dolar, 2013 y1lında da İran'dan 507 dolar, Rusya'dan 428 dolar olmuştur. Bu süreçte Azerbaycan doğalgazının fiyatı ise 349 dolara kadar gerilemiştir. ${ }^{23}$

TANAP'ın yalnızca Türkiye ve Azerbaycan'ın finansal ve teknolojik imkânları kullanılarak gerçekleştiriliyor olması, bu projenin Türk-Azeri işbirliğini içeren bir girişim olması açısından önemlidir. Türkiye ve Azerbaycan'ın Avrupa ve diğer uluslararası piyasalara müşterek çıkması (Aras vd., 2013: 996), iki ülke arasındaki işbirliğinin gelişim sürecinin diğer ülkelerce dikkatle izlenmesine sebep olmuştur.

\subsection{Trans Hazar-TANAP Entegrasyonu ile Projenin Genişlemesi}

TANAP Projesinin realizasyonu sürecinde üzerinde durulması gereken bir diğer alternatif uzantı, doğalgaz rezervleri açısından dünyada dördüncü önemli ülke olan Türkmenistan'ın, sahip olduğu doğalgazı Hazar Denizi'nin altından yaklaşık $300 \mathrm{~km}$ 'lik bir boru hattı ile (Trans Hazar Boru Hattı Projesi) kendi kaynakların Batı pazarlarına ulaştırmak istemesi ve bunun için de Hazar-Türkiye ayağında TANAP

\footnotetext{
${ }^{22}$ http:// www.cnnturk.com/ekonomi/sirketler/turkiyenin-tanaptaki-hissesi-artirildi (Erişim Tarihi: 25.12.2013)

23 "Türkiye Hangi Ülkeden Kaç Liraya Doğalgaz Alıyor?"

http://enerjienstitusu.com/2013/03/31/turkiye-hangi-ulkeden-kac-liraya-dogalgaz-aliyor/
} (Erişim Tarihi: 04.01.2014) 


\section{| MEHMET DİKKAYA ve ABDÜLKADİR TIĞLI}

Hattı'na entegre olmak istemesidir. Azerbaycan da bu girişime sıcak bakmakta fakat Hazar Denizi'nin hukuki statüsü netlik kazanmadığı için bu konuda adım atılamamaktadır (Turan, 2010: 49).

Türkmen doğalgazının Hazar üzerinden Batı'ya açılması ve bu eksende Türkmenistan'ın doğalgaz ihracatının artması, Azerbaycan ve Türkiye'nin de iletim hattı rolünü üstlenmesinin, bu üç ülkenin enerji iletimi konusunda uluslararası piyasalarda önemli ölçüde söz sahibi olacağının parametreleri sayılabilir. Böylece 2007 yılına kadar doğalgazda Rusya'ya bağımlı iken, 2011 ve sonrasında önemli bir doğalgaz ihracatçısı konumuna gelen Azerbaycan, kendi kaynakları açısından üretim ve ihracat kapasitesini genişletecek; Türkmen doğalgazı açısından transit ülke olma özelliği taşıyarak Batı'nın doğalgazda Rusya'ya bağımlılığının azaltmasında önemli bir rol üstlenebilecektir.

\section{4. Şah Deniz-II Anlaşması ve TANAP Üzerindeki Etkisi}

Doğalgaz üretim ve iletimine ilişkin uluslararası ajandada hareketliliğin ortaya çıkmasına neden olan önemli bir olay 17 Aralık 2013 tarihinde Azerbaycan'da, Şah Deniz-II doğalgaz yataklarından gaz üretimi ve paylaşımını öngöre bir anlaşma imzalanmıştır. TANAP ve TAP projelerinin akıbetini etkileme potansiyeli olan bu anlaşma, Azerbaycan merkezli olmak üzere Güney Kafkasya'nın dış pazarlara daha çok açılmasında özel bir önem taşımaktadır.

TANAP, TAP ve Şah Deniz-II anlaşması ekseninde toplam yatırım miktarının 35 milyar dolar olacağ 1 öngörülen bu gelişme, gaz üretim tesislerinden başlayarak güzergâh üzerinde on binlerce yeni iş imkânı sağlayacak, Azerbaycan'ın ihracatını çeşitlendirmesi, Avrupa enerji güvenliğini pekiştirmesi ve güzergâhın transit ülkeleri olan Azerbaycan-Gürcistan-Türkiye-Yunanistan-İtalya hattında uzanan geniş bir coğrafyada yeni bir ekonomik dinamizm ortaya çıkarabilecek olması yönüyle önemlidir.

BP (\%25), Statoil (\%10), SOCAR (\%10) ve TPAO (\%9) gibi dev şirketler tarafından imzalanan anlaşma çerçevesinde üretilecek yıllık 16 milyar $\mathrm{m}^{3}$ doğal gaz, 3500 km mesafe kat ederek İtalya'ya kadar gönderilecektir. Böylece Şahdeniz-I'den halen üretilen 9 milyar $\mathrm{m}^{3}$ doğal gaz 2018 yılına kadar 16 milyar $\mathrm{m}^{3}$ e çıkarılacaktır. Bu miktarın 6 milyar m³ $^{3}$ ü Türkiye'nin, kalanı da Avrupa için bir sonraki yıl kullanılmaya başlanacaktır (Dikkaya, 2014). 
Oldukça uzun vadeli (25 yıl) bir gaz üretim anlaşmasının imzalandığı bu yeni kaynaktan elde edilecek gazın müşterileri hazırdır. Üç Avrupa ülkesinden (İtalya, Yunanistan ve Bulgaristan) 9 şirketin bu gazı satın alabileceğini deklare etmesi ve Avrupa'dan gelen bu gaz kaynağına yönelik yüksek ilgi, Azerbaycan'ın tahmin edilen gaz rezerv miktarını (yaklaşık 3 trilyon $\mathrm{m}^{3}$ ) yeniden hesaplamayı gerektirecek kadar (iki katına çıkması beklenecek şekilde) bölge açısından önemlidir. Türkiye, BTE hattı ekseninde hali hazırda yıllık 6 milyar $\mathrm{m}^{3}$ doğalgaz alımı yapmakta, Şahdeniz II gazının üretilmeye başlamasının ardından bir o kadar daha satın alım taahhüdünde bulunmaktadır. İç talebin yıllık 50 milyar $\mathrm{m}^{3}$ civarında olduğu Türkiye ve bölge için bu anlaşmanın sonuçları oldukça önemlidir (Dikkaya, 2014).

\section{SONUÇ}

Yakın tarihte, gerek sahip olduğu enerji kaynakları, gerekse Orta Asya enerji kaynaklarının Batı'ya iletimi konusunda koridor görevi üstlenen Güney Kafkasya, artan bir ivmeyle uluslararası kamuoyunun dikkatini çekmeye devam etmektedir. Bunun iki ayağı olduğunu görmek mümkündür. Bunlardan ilki, sanayileşen ekonomilerin artan enerji ihtiyacı karşısında, enerji güvenliğinin sağlanmasıdır. İkincisi ise, Orta Asya ve Hazar enerji kaynaklarının üretim, işletim ve iletim sektörlerinden pay alma yarışına giren çok uluslu şirketlerin varlığı ile ilgilidir.

Sanayi üretiminin artması ile dikkat çeken Doğu ve Güney Asya ülkelerinin, yüksek büyüme rakamlarına paralel olarak artan enerji ihtiyacı; Batı dünyasını enerji güvenliği konusunda kaygılandırmaktadır. Enerji güvenliğinde şu an itibarı ile esas üzerinde durulan faktör Rusya'dır. Zira doğalgaz sevkiyatında ilk sırada yer alan Rusya'nın güdümünde kalmak, zaman zaman yaşanan siyasi ve askeri krizler karşısında Rusya'nın, bu potansiyeli Batı'ya karşı bir tehdit unsuru olarak kullanmasına sebep olmaktadir.

Batı'nın enerji güvenliğine endekslediği enerji ihtiyacı, ithalatçı ülkeleri diğer Orta Asya ülkelerine yönlendirmiştir. Avrasya doğalgaz rezervi bakımından Rusya'dan sonra gelen Türkmenistan ve Kazakistan'dan elde edilen doğalgazın AB ülkeleri ve diğer ülkelere güvenli bir şekilde sevk edilmesi gündeme gelince, hem kaynak bakımından Hazar bölgesi, Türkmenistan ve Kazakistan, hem de iletim hattı bakımından Güney Kafkasya coğrafyası ve Türkiye ön plana çıkmıştır. 


\section{| MEHMET DİKKAYA ve ABDÜLKADİR TIĞLI}

Güney Kafkasya ülkelerinden Azerbaycan, iletim hattı üzerinde olmasının yanı sıra Hazar Denizi'ne kıyısı olması ve zengin petrol ve doğalgaz kaynaklarına sahip olmasıyla da Güney Kafkasya coğrafyasının en önemli aktörü konumundadır. Azeri gazının Batı'ya iletimi, hem Transkafkasya'yı hem de Türkiye'yi güvenli bir enerji koridoru haline getirmiştir. Batı hattında gelişen iki rakip proje Nabucco ve TAP'ın, Azeri gazına erişimini sağlamak için oluşturulan TANAP Projesi ise, bu minvalde önemli bir konuma yerleşmiştir. TAP ile girdiği rekabet sonucu fazla destek göremeyen Nabucco ise, yakın zamanda çekilerek TANAP'ın Avrupa'ya iletim işlevini TAP'a birakmıştır.

TANAP ile Türkiye de bugüne kadar Rusya ve İran'dan yüksek maliyetli fiyatlarla ithal ettiği gazın yerine daha ucuz gaz elde edecek, aynı zamanda Avrupa'ya iletilecek gazın fiyatı da ucuzlayacaktır. Bu, kısa vadeli bir kazanım iken, orta ve uzun vadede Hazar Denizi'nin hukuki statüsü üzerinde sağlanabilecek uluslararası konsensus ile Türkmen gazının Hazar üzerinden TANAP'a bağlanması, enerji güvenliği açısından İran ve Rusya faktörü karşısında Avrupa ve Türkiye'nin elini rahatlatacaktır.

TANAP'ın belki de bahsedilmesi gereken en önemli yanı, Azerbaycan ve Türkiye'nin, üçüncü bir ülke veya şirketin gözetimi ya da finansmanına ihtiyaç duymadan ortak bir projeyi hayata geçirmeye çalışmalarında gizlidir. Kafkasya'da bölgesel özgüveni gösteren ilk uluslararası proje olarak gösterilen Kars-Tiflis-Bakü demiryolu projesinin ardından TANAP'ın devreye girecek olması, hem bölgesel ekonomik dinamizmin bir sonucu hem de Bakü-Tiflis-Ankara düzleminde Kafkasya'da oluşacak bölgesel entegrasyon düşüncesinin somut bir göstergesi olacaktır.

\section{KAYNAKLAR}

Abbasov, S. (2010), “Turkey, Azerbaijan Gas Agreement Reached, but Talks to Continue". http://www.eurasianet.org/node/61234 (Erişim Tarihi: 02.12.2014)

Aras, O. N. (2003), Azerbaycan Ekonomisi - Makro Ekonomik ve Sektörel Analiz. Bakü: Kafkasya Araştırmaları Merkezi Yayınları.

Aras, O. N.; Suleymanov, E.; Hasanov F. (2013), “Economic and Strategic Expactations of Trans-Anatolian Natural Gas Pipeline Project", Munich Personal Repec Archive, 52187, 991-998.

http://mpra.ub.uni-muenchen.de/52187/1/MPRA_paper_52187.pdf

(Erişim Tarihi: 06.01.2014) 
Aslanlı, A. (2011), “Kafkasya'da Güvenlik ve İstikrara En Büyük Tehdit: Karabağ Sorunu", Cavid Veliev ve Araz Aslanlı (der.), Güney Kafkasya; Toprak Bütünlüğü, Jeopolitik Müdahaleler ve Enerji içinde, 153-192. Ankara: Berikan Yayınevi.

Baloğlu, M. (2010), "Azerbaycan Devlet Petrol Şirketi (SOCAR) Yatırımlarının Türkiye Ekonomisine Etkilerinin Değerlendirilmesi", http://papers.ssrn.com/sol3/papers.cfm?abstract_id=2257961 (Erişim Tarihi: 19.12.2013)

Brzezinski, Z. (2005), Büyük Satranç Tahtası. Yelda Türedi (çev.). İstanbul: İnkılâp Kitabevi.

Cafersoy, N. (2011), “Bağımsızlığının 20.Yılında Azerbaycan”, Cavid Veliev ve Araz Aslanlı (der.), Güney Kafkasya; Toprak Bütünlüğü, Jeopolitik Müdahaleler ve Enerji içinde, 13-56. Ankara: Berikan Yayınevi.

Çelikpala, M. (2010), “Türkiye ve Kafkasya: Reaksiyoner Dış Politikadan Proaktif Ritmik Diplomasiye Geçiş", Uluslararası İlişkiler Akademik Dergisi, 7:25, 93126

http:/ / ataum.gazi.edu.tr/posts/view/title/turkiye\%E2\%80\%99nin-orta-asyave-kafkasya $\%$ E2\%80\%99daki-bolgesel-politikasinda-enerji-guvenligi-47389 (Erişim Tarihi: 05.12.2013)

Davutoğlu, A. (2010), Stratejik Derinlik, İstanbul: Küre Yayınları.

Denizhan, E. (2010), “Türkiye'nin Kafkasya ve Orta Asya Politikası ve TİKA”, Sosyal ve Beşeri Bilimler Dergisi, 2:1, 17-23

http://www.sobiad.org/ejournals/dergi_SBD/arsiv/2010_1/03emrah_denizh an.pdf (Erişim Tarihi: 11.12.2013)

Dikkaya, M. (2009), Orta Asya ve Kafkasya: Dönüşüm Süreci ve Uluslararası Ekonomi Politik, İstanbul: Beta Yayıncilik.

Dikkaya, M. (2014). “Şah Deniz-II Anlaşmasının (17 Aralık 2013) Bölgesel Gaz Denklemi Açısından Önemi"

http:/ / www.usgam.com/tr/index.php?l=800\&cid=2179\&konu=16\&bolge=0 (Erişim Tarihi: 11.02.2014)

Gökdemir, B. (2009), "Türkiye'de Doğalgaz Sektörünün Yeniden Yapılandırılması: Sekiz Yıllık Deneyimin Arz Güvenliği ve Rekabet Politikası Perspektifinden 


\section{| MEHMET DİKKAYA ve ABDÜLKADİR TIĞLI}

Değerlendirilmesi", Türkiye Ekonomi Politikaları Araştırma Vakfı Yayınları, 43, http://www.tepav.org.tr/tr/yayin/s/158,(Erişim Tarihi: 15.12.2013)

Hekimoğlu, M. M. (2012), “Bakü-Tiflis-Ceyhan Boru Hattı Projesinin Hukuki Boyutları", Bilig Türk Dünyası Sosyal Bilimler Dergisi, 63, 77-92

http:/ / yayinlar.yesevi.edu.tr/index.php?action=show_article\&bilig_id=52\&art icle_id=756 (Erişim Tarihi: 03.12.2013)

İşcan, İ. H. (2010), "Uluslararası Enerji Güvenliği Açısından Hazar Bölgesi Enerji Ekonomisi ve Hazar Denizi'ni Paylaşım Sorunu". Sosyoekonomi Dergisi, Özel Sayı (10EN04).

http:/ / dergipark.ulakbim.gov.tr/sosyoekonomi/article/view/5000080574/500 0074614 (Erişim Tarihi: 22.04.2015)

Kantarc1, H. (2006), “Soğuk Savaş Sonrası Kafkasya'da ABD ve Rusya'nın Güç Mücadeleleri ve Bu Mücadelelerin Türkiye'ye Etkileri”, Suleyman Demirel University Research Repository, Masters Thesis.

http:/ / eprints.sdu.edu.tr/358/1/TS00519.pdf (Erişim Tarihi: 11.11.2013

Kantarc1, Ş. (2011), “Kafkasya'da Etnik Çatışmalar Ekseninde “Güney Osetya” Sorunu", Cavid Veliev ve Araz Aslanlı (der.), Güney Kafkasya; Toprak Bütünlüğü, Jeopolitik Müdahaleler ve Enerji içinde, 229-288 Ankara: Berikan Yayınevi

Kasım, K. (2011), Soğuk Savaş Sonrası Kafkasya. Ankara: USAK Yayınları.

Metin, M. (2004), Politik ve Bölgesel Güç Hazar, İstanbul: IQ Kültür-Sanat Yayıncıllı.

Oğan, S. (2011), "Kafkasya'da Etnik Çatışmalar Ekseninde Abhazya Sorunu”, Cavid Veliev ve Araz Aslanlı (der.), Güney Kafkasya; Toprak Bütünlügüu, Jeopolitik Müdahaleler ve Enerji içinde, 193-228 Ankara: Berikan Yayınevi.

Oruç, T. Ç. (2014), "Kıyıdaş Devletlerin Talepleri Çerçevesinde Hazar'ın Hukuki Statüsü ve Paylaşılması Sorunu". Bilge Adamlar Stratejik Araştırmalar Merkezi. http:/ / www.bilgesam.org/Images/Dokumanlar/0-2672014062515asya_bol3.pdf (Erişim Tarihi: 22.04.2015)

Öğütçü, M. (2010), “Küreselden Yerele Enerjide Gelecek ve Seçeneklerimiz”, Durmuş Dündar, Müge İşeri ve Necdet Pamir (ed.) Enerji Güvenliği Dünya ve Türkiye Paneli içinde, 109-130 İstanbul: İstanbul Kültür Üniversitesi Yayınları. 
Pamir N. (2011), “Güney Kafkasya ve Enerji”, Cavid Veliev ve Araz Aslanlı (der.), Güney Kafkasya; Toprak Bütünlüğü, Jeopolitik Müdahaleler ve Enerji içinde, 345-394 Ankara: Berikan Yayınevi.

Rzayeva, G. (2012), “TANAP: Hazar Gazını Avrupa'ya Taşıyacak Atılım Projesi",http://www.hazar.org/content/yayinlar/tanap_hazar_gazini_avrupa' ya_tasiyan_atilim_projesi_247.aspx (Erişim Tarihi: 30.11.2013)

Rzayeva, G.; Punsmann, B. G. ve Göknel, M. M. (2012), “Trans Anadolu Doğal Gaz Boru Hattı TANAP Raporu", Hazar Strateji Enstitüsü.

http://www.hazar.org/UserFiles/yayinlar/raporlar/2012_09_19_tanap_rapor u/TANAPRaporu_121107.pdf (Erişim Tarihi: 29.11.2013)

Sagheb, N. ve Cavadi, M. (1994), "Azerbaijan's 'Contract of The Century' Finally Signed With Western Oil Consorsium". Azerbaijan International Magazine, 2(4), 26-28. http://www.azer.com/aiweb/categories/magazine/24_folder/24_articles/24_ aioc.html (Erişim Tarihi: 26.04.2015)

Şen, L. (2009), Türkiye ve Güney Kafkasya Gerçeği-Soğuk Savaş Sonrası Türkiye'nin Güney Kafkasya Politikası, Ankara: Ürün Yayınları.

Taşdemir, H. ve Hasanoğlu, M. (2003), Kafkasya'nın Etnik Yapısı ve Etnik Çatışma, Türkiye Sosyal Araştırmalar Dergisi, 1, 93-110

http://dokuman.tsadergisi.org/dergiler_pdf/2003/2003-nisan/11.pdf (Erişim Tarihi: 05.12.2013)

Turan, A. P. (2010), "Hazar Havzası'nda Enerji Diplomasisi”.

http://www.bilgesam.org/tr/images/stories/makaleler/Hazar\%20Havzasind a\%20Enerji\%20Diplomasisi.pdf (Erişim Tarihi: 30.11.2013)

Veliev, C. (2011), “Bağımsızlığının 20.Yılında Ermeni Dış Politikası”, Cavid Veliev ve Araz Aslanlı (der.), Güney Kafkasya; Toprak Bütünlüğ̈̈, Jeopolitik Müdahaleler ve Enerji içinde, 105-152 Ankara: Berikan Yayınevi.

World Energy Council (2013), "World Energy Resources: Natural Gas". http://www.worldenergy.org/wpcontent/uploads/2013/10/WER_2013_3_Natural_Gas.pdf

(Erişim Tarihi: 11.01.2014)

Yıldıran, M. (2013), “İpekyolu Çerçevesinde Enerji Ekonomilerinin Yükselişi ve Enerji

Üzerindeki Rekabet: Potansiyel, Stratejiler ve Yeni Büyük Oyun", Avrasya 


\section{| MEHMET DİKKAYA ve ABDÜLKADİR TIĞLI}

Etüdleri, 43(1), 105-138. http:/ / store.tika.gov.tr/yayinlar/akademikarastirmalar/avrasya-etudleri/2013/etud43.pdf (Erişim Tarihi: 14.11.2013)

Yılmaz, R. (2009). "Azerbaycan'ı ve Azerbaycanlıyı Anlayabilmek". Uluslararası Stratejik Araştırmalar Kurumu.

http:/ / www.usak.org.tr/analiz_det.php?id=17\&cat=365366301\#.VUUZVTqJjI

U (Erişim Tarihi: 21.04.2015)

Yılmaz, R. (2012), Azerbaycan Dış Politiği ve Türkiye. Çankırı: Çankırı Karatekin Üniversitesi Avrasya Stratejik Araştırmalar Merkezi Avrasya Araştırmaları Serisi-2.

Yılmaz, R. (2013), "Kafkasya'da Çözülemeyen Kördüğüm: Dağlık Karabağ Sorunu". Çankırı Karatekin Üniversitesi Uluslararası Avrasya Strateji Dergisi, 2(1), 71-90. http://www.arastirmax.com/system/files/dergiler/169983/makaleler/2/1/ar astrmx_169983_2_pp_71-90.pdf (Erişim Tarihi: 25.04.2015) 
